\title{
PIK3R5 Gene
}

National Cancer Institute

\section{Source}

National Cancer Institute. PIK3R5 Gene. NCI Thesaurus. Code C124254.

This gene plays a role in the regulation of phosphoinositide-3-kinase gamma activity. 